\title{
Gambaran Angka Kejadian Tentamen Suicidum pada Penderita Gangguan Jiwa di RS Jiwa H.B Saanin Periode Januari-Desember 2013
}

Utari Gestini Rahmi ${ }^{1}$, Yaslinda Yaunin ${ }^{2}$, Rima Semiarti ${ }^{3}$

\begin{abstract}
Abstrak
Tentamen Suicidum merupakan fenomena sosial yang banyak terjadi di Indonesia. Lebih 90\% diantaranya terdiagnosa gangguan jiwa. Tujuan penelitian ini adalah untuk mengetahui persentase kejadian tentamen suicidum dan karakteristik pasien yang melakukan tentamen suicidum di RSJ Prof. H.B. Saanin. Penelitian deskriptif ini dilakukan terhadap 90 pasien tentamen suicidum di RSJ Prof. H.B. Saanin periode Januari-Desember 2013. Data yang diambil dari Instalasi Rekam Medis RSJ Prof.H.B. Saanin adalah karakteristik dari pasien tentamen suicidum .Hasil ditampilkan dalam bentuk tabel distribusi frekuensi. Hasil penelitian ini didapatkan bahwa angka kejadian tentamen suicidum di RSJ Prof.HB Saanin sebanyak 90 kasus (4,2\%) dari 2142 pasien yang dirawat inap di RSJ Prof.H.B. Saanin selama tahun 2013. Dari kasus yang diteliti diperoleh bahwa tindakan ini lebih banyak dilakukan oleh pasien berumur $26-45$ tahun $(50 \%)$, jenis kelamin laki-laki $(68,9 \%)$, menggunakan benda tajam baik pada laki-laki $(19,35 \%)$ maupun pada wanita $(28,57 \%)$, belum menikah pada laki-laki $(70,97 \%)$ dan menikah pada wanita $(53,57 \%)$, pendidikan SMA-sederajat $(32,2 \%)$, tidak bekerja $(45,6 \%)$ dan skizofrenia paranoid baik pada laki-laki maupun wanita $(50 \%)$. Simpulan studi ini adalah kejadian tentamen suicidum tinggi pada, usia dewasa, laki-laki, tamat SMA, belum menikah, pengangguran, menggunakan benda tajam, dan menderita skizofrenia paranoid.
\end{abstract}

Kata kunci: gangguan jiwa, RSJ HB Saanin, tentamen suicidum

\section{Abstract}

Tentament suicide is a social phenomenon that often occurs in Indonesia. More than $90 \%$ of cases diagnosed with mental disorders. The objective of this study was to determine the percentage and characteristics of tentament suicide in HB Saanin Mental Hospital. A decriptive study was conducted in 90 patients of tentament suicidum in HB Saanin Mental Hospital during January - December 2013. Data was taken from the Installation of Medical Record is characteristics of patients with tentament suicidum. The result displayed in frequency of distribution table. From the result, it was known that the number of tentament suicide cases in HB Saanin Mental Hospital were 90 (4,2\%) from 2142 examined ceses. From the examined cases it was found that most of cases was were patients 26-45 years old (50\%) , men (68,9\%), with sharp instrument both in men (19,35\%) and women (28,57\%), unmarried men (70,97\%) and women (53,57\%), graduated from SMA (32,2\%), unemployed (45,6\%), schizophren paranoid both men and woman (50\%). It can be concluded that most of cases were adult, men, graduated from SMA, unmarried, unemployed, with sharp instruments and schizofren paranoid.

Keywords: mental disorders, HB Saanin Mental Hospital, tentament suicide

Affiliasi penulis: 1. Prodi Profesi Dokter FK Unand (Fakultas Kedokteran Universitas Andalas Padang), 2. Bagian Kedokteran Jiwa FK Unand, 3. Bagian IImu Kesehatan Masyarakat FK Unand Korespondensi: Utari Gestini Rahmi, email: utarigestini@gmail.com, Telp: 081267603007

\section{PENDAHULUAN}

Bunuh diri adalah tindakan yang secara sengaja mematikan dirinya sendiri. Di kalangan dunia medis bunuh diri dianggap sebagai "kanker", sehingga 
psikiater diharapkan dapat menangani dengan baik agar pasien tidak meninggal karena bunuh diri. ${ }^{1}$ Bunuh diri merupakan fenomena sosial yang sangat penting dan membutuhkan perhatian tidak hanya dari psikiater tapi juga masyarakat umum. ${ }^{2}$

Fenomena bunuh diri telah meluas hampir di seluruh belahan dunia, baik di negara yang maju teknologinya maupun di negara berkembang, dari negara-negara kaya sampai negara miskin. ${ }^{3}$ Riset mengenai bunuh diri telah dimulai oleh Durkheim pada tahun 1858-1917 yang menyatakan bahwa alasan seseorang bunuh diri adalah karena lemahnya interaksi individu manusia dengan manusia lainnya. ${ }^{4}$

Pada tahun 2020 diperkirakan 1,53 juta orang akan mati karena bunuh diri di seluruh dunia, artinya akan terjadi 1 kematian setiap 20 detik. ${ }^{5}$ Bunuh diri merupakan masalah psikologis dunia yang sedang mengancam saat ini. Angka bunuh diri di negaranegara Eropa menempati urutan tertinggi. Urutan pertama diduduki Jerman dengan angka 37 orang per 100.000 penduduk. Republik Ceko, Selandia Baru, Austria, dan Swiss juga memiliki insiden yang tinggi. Sedang untuk negara Austria, Denmark, Inggris ratarata 23 orang per 100.000 penduduk. Di Amerika Serikat tiap tahunnya terdapat sekitar 500.000 orang yang ditangani di Unit Gawat Darurat yang mengalami percobaan bunuh diri dan lebih dari 30.000 berhasil dalam mengakhiri hidup mereka. ${ }^{6} \mathrm{Di}$ Indonesia, selama tahun 2003 ditemukan 112 kasus bunuh diri dan tahun 2004 mengalami peningkatan, selama 6 bulan pertama saja sudah ditemukan 92 kasus. Jumlah kasus bunuh diri di Indonesia jauh lebih sedikit dibandingkan Amerika Serikat, namun angka kejadian bunuh diri di Indonesia meningkat dari tahun ke tahun. ${ }^{7}$ Pada tahun 2005, sedikitnya 50.000 orang Indonesia melakukan tindak bunuh diri tiap tahunnya. Terdapat beberapa faktor penyebab nekadnya seseorang melakukan bunuh diri, diantaranya: pengangguran, tingkat kemiskinan yang terus bertambah, mahalnya biaya sekolah, kesehatan dan biaya hidup, penggusuran, kesenjangan kaya miskin, dan pasien gangguan mental terutama depresi yang tidak ditangani secara optimal. ${ }^{1}$

Keinginan bunuh diri terjadi pada semua kelompok umur termasuk pada anak dan remaja dengan gangguan mood yang berat. Lebih dari 12.000 anak dan remaja dirawat di rumah sakit Amerika Serikat setiap tahunnya akibat ancaman atau tindakan bunuh diri, namun bunuh diri yang berhasil dilakukan jarang terjadi pada anak di bawah 12 tahun. ${ }^{8}$ Fenomena bunuh diri pada anak dan remaja di Indonesia menjadi perhatian publik sejak 1998. Komisi Nasional Perlindungan Anak (Komnas Anak) dalam laporannya pada pertengahan tahun 2012 menyebutkan bahwa dari bulan Januari sampai dengan Juli 2012, sudah terjadi 20 kasus bunuh diri pada anak. Menurut Ketua Umum Komnas Perlindungan Anak, Arist Merdeka Sirait yang dikutip oleh Rozaki (2012), dari 20 kasus tersebut, penyebab bunuh diri terbanyak adalah urusan putus cinta remaja, frustasi akibat ekonomi, anak yang berasal dari keluarga yang tidak harmonis, dan masalah sekolah. Kasus bunuh diri pada anak termuda adalah

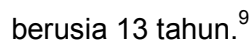

Di Sumatera Barat telah dilakukan penelitian terhadap tindakan percobaan bunuh diri (tentament suicidum) di RSJ Pusat pada tahun 1997-1999 dan diperoleh bahwa angka kejadian tentamen suicidum sebanyak 118 kasus $(5,87 \%)$, sedangkan kejadian non tentamen suicidum adalah 1892 kasus (94,13\%) dari 2010 kasus yang diperiksa pada pasien rawat inap. ${ }^{10}$

Beberapa riset menjelaskan bahwa bunuh diri dapat diturunkan secara genetik, ada juga yang berpendapat bahwa bunuh diri bisa berhubungan dengan trauma atau stress masa kecil dimana bunuh diri dianggap sebagai masalah filosofi, fenomena sosiologi serta dilema analitis atau eksistensialis. Risiko bunuh diri lebih besar pada orang dengan gangguan mood yang parah, seperti depresi mayor dan gangguan bipolar. Sekitar 20\% hingga 35\% kematian karena bunuh diri di Amerika Serikat disebabkan oleh depresi mayor. Satu dari lima orang dengan gangguan bipolar pada akhirnya melakukan bunuh diri. Percobaan maupun keberhasilan bunuh diri juga dihubungkan dengan gangguan psikologis lainnya, seperti alkoholisme dan ketergantungan obat, skizofrenia, gangguan panik, gangguan kepribadian antisosial, gangguan stres pasca trauma dan gangguan kepribadian ambang. ${ }^{6}$ 
Berdasarkan penjabaran tersebut, penulis tertarik untuk melakukan penelitian mengenai angka kejadian tentamen suicidum pada penderita gangguan jiwa di RS Jiwa HB Saanin.

\section{METODE}

Penelitian ini merupakan studi deskriptif terhadap jumlah penderita gangguan jiwa yang dirawat inapkan di RSJ Prof. H.B. Saanin yang pernah mencoba bunuh diri selama tahun 2013

Populasi penelitian adalah pasien gangguan jiwa di RSJ Prof. H.B. Saanin yang melakukan tentamen suicidum tahun 2013 sebanyak 90 orang.

Data rekam medik yang terkumpul diidentifikasi data pasien yang mengalami tentamen suicidum kemudian dibuat persentase kasusnya berdasarkan umur, jenis kelamin, metoda, agama, status perkawinan, pekerjaan, pendidikan, dan diagnosa psikiatri sehingga didapatkan gambaran tentang angka kejadian tentamen suicidum pada penderita gangguan jiwa berdasarkan umur, jenis kelamin, metoda, agama, status perkawinan, pekerjaan, pendidikan dan diagnosa psikiatri.

\section{HASIL}

Telah dilakukan penelitian terhadap pasien rawat inap RSJ Prof. H.B. Saanin periode JanuariDesember 2013. Data diambil dari Instalasi Rekam Medis RSJ HB Saanin yang dikepalai oleh Masriri, S.Sos. Instalasi Rekam Medis ini mempunyai empat bidang pekerjaan diantaranya: urusan pendaftaran pasien, pengolahan data, pelaporan serta penyimpanan dan administrasi umum. Data yang didapat adalah data selama tahun 2013 yang mencakup jumlah kasus keseluruhan dan jumlah kasus tentamen suicidum serta distribusinya berdasarkan umur, jenis kelamin, metoda, agama, status perkawinan, pendidikan, pekerjaan dan diagnosis psikiatri.
Tabel 1. Data kejadian tentamen suicidum dan non tentamen suicidum

\begin{tabular}{lcc}
\hline \multicolumn{1}{c}{ Jenis tindakan } & $\mathbf{f}$ & $\%$ \\
\hline Tentamen suicidum & 90 & 4,2 \\
Non tentamen suicidum & 2052 & 95,8 \\
\hline Jumlah & 2142 & 100 \\
\hline
\end{tabular}

Berdasarkan Tabel 1 didapatkan kejadian tentamen suicidum di RSJ Prof. H.B. Saanin pada tahun 2013 adalah 4,2\% sedangkan kejadian non tentamen suicidum adalah $95,8 \%$.

Tabel 2. Data kejadian tentamen suicidum menurut umur

\begin{tabular}{lcccc}
\hline \multirow{2}{*}{ Umur } & \multicolumn{4}{c}{ Jenis kelamin } \\
\cline { 2 - 5 } & Laki-laki & $\%$ & wanita & $\%$ \\
\hline $12-25$ & 24 & 38,71 & 3 & 10,71 \\
$26-45$ & 33 & 53,23 & 14 & 50 \\
$\geq 46$ & 5 & 8,06 & 11 & 39,29 \\
\hline Total & 62 & 100 & 28 & 100 \\
\hline
\end{tabular}

Data kejadian tentamen sucidium berdasarkan umur pada Tabel 2, didapatkan bahwa pasien yang mengalami tentamen suicidum di RSJ Prof. H.B. Saanin pada tahun 2013 terbanyak adalah pada usia 26-45 tahun baik pada laki-laki $(53,23 \%)$ maupun wanita $(50 \%)$. Sedangkan untuk persentase terendah pada laki-laki yaitu pasien 46 tahun keatas sebanyak $8,06 \%$ dan pada wanita yaitu pasien berumur $12-25$ tahun sebanyak $10,71 \%$.

Tabel 3. Data kejadian tentamen suicidum menurut jenis kelamin.

\begin{tabular}{lcc}
\hline \multicolumn{1}{c}{ Jenis kelamin } & $\mathbf{f}$ & $\%$ \\
\hline Laki-laki & 62 & 68,9 \\
Wanita & 28 & 31,1 \\
\hline Jumlah & 90 & 100
\end{tabular}


Berdasarkan Tabel 3 didapatkan bahwa kejadian tentamen suicidum di RSJ Prof. H.B. Saanin pada tahun 2013 lebih banyak terjadi pada laki-laki $(68,9 \%)$ dibandingkan wanita $(31,1 \%)$.

Tabel 4. Data kejadian tentamen suicidum menurut metoda

\begin{tabular}{lllll}
\hline Metoda & $\begin{array}{l}\text { Laki- } \\
\text { laki }\end{array}$ & wanita & \% \\
\hline racun pestisida & 8 & 12,9 & 0 & \\
Zat kimia lainnya & 5 & 8,06 & 0 & \\
Gantung diri & 7 & 11,3 & 6 & 21,43 \\
Membenamkan/menen & 2 & 3,23 & 0 & \\
ggelamkan kepala & & & & \\
Membakar diri & 6 & 9,68 & 0 & \\
Benda tajam & 12 & 19,35 & 8 & 28,57 \\
Meloncatdari ketinggian & 6 & 9,68 & 3 & 10,71 \\
Menabrakkan diri & 0 & 0 & 1 & 3,57 \\
Membenturkan kepala & 5 & 8,06 & 4 & 14,29 \\
Tidak diketahui & 11 & 17,74 & 6 & 21,43 \\
Total & 62 & 100 & 28 & 100 \\
\hline
\end{tabular}

Tabel 4 menunjukkan bahwa metoda bunuh diri yang dilakukan oleh pasien yang mengalami tentamen suicidum di RSJ Prof. H.B. Saanin pada tahun 2013, paling banyak adalah dengan menggunakan benda tajam baik pada laki-laki $(19,35 \%)$ maupun pada wanita $(28,57 \%)$.

Tabel 5. Data kejadian tentamen suicidum ditinjau berdasarkan agama

\begin{tabular}{cll}
\hline Agama & $\mathbf{f}$ & $\%$ \\
\hline Islam & 84 & 93,3 \\
Protestan & 2 & 2,2 \\
Katholik & 2 & 2,2 \\
Budha & 2 & 2,2 \\
\hline Total & 90 & 100 \\
\hline
\end{tabular}

Berdasarkan Tabel 5 didapatkan bahwa kejadian tentamen suicidum di RSJ Prof.H.B. Saanin pada tahun 2013 paling tinggi pada pasien beragama Islam (93,3\%).
Tabel 6. Data kejadian tentamen suicidum menurut status perkawinan

\begin{tabular}{lcc}
\hline \multicolumn{1}{c}{ Status perkawinan } & $\mathbf{f}$ & \% \\
\hline Menikah & 23 & 25,6 \\
Belum menikah & 53 & 57,8 \\
Duda/janda & 15 & 16,7 \\
\hline Jumlah & 90 & 100 \\
\hline
\end{tabular}

Tabel 6 menunjukan bahwa angka kejadian tentamen suicidum lebih sering terjadi pasien yang belum menikah $(57,8 \%)$.

Tabel 7. Data kejadian tentamen suicidum menurut pendidikan

\begin{tabular}{lcc}
\hline \multicolumn{1}{c}{ Tingkat pendidikan } & f & \% \\
\hline Tidak sekolah & 2 & 2,2 \\
SD & 22 & 24,4 \\
SMP-sederajat & 27 & 30,0 \\
SMA-sederajat & 29 & 32,2 \\
Perguruan Tinggi & 10 & 11,1 \\
\hline Total & 90 & 100
\end{tabular}

Berdasarkan Tabel 7 didapatkan bahwa pasien yang mengalami tentamen suicidum di RSJ Prof. H.B. Saanin pada tahun 2013 paling banyak berlatar belakang pendidikan SMA-sederajat $(32,2 \%)$, angka ini tidak jauh berbeda dengan SMP-sederajat $(30,0 \%)$.

Tabel 8. Data Kejadian tentamen suicidum menurut pekerjaan

\begin{tabular}{lcc}
\hline Pekerjaan & $\mathbf{f}$ & $\%$ \\
\hline Pelajar/mahasiswa & 9 & 10,0 \\
Buruh & 2 & 2,2 \\
Tani & 6 & 6,7 \\
Dagang/wiraswasta & 10 & 11,1 \\
PNS & 5 & 5,6 \\
Pegawai swasta & 5 & 5,6 \\
IRT & 9 & 10,0 \\
Sopir & 1 & 1,1 \\
Tukang jahit & 1 & 1,1 \\
Bengkel & 1 & 1,1 \\
Tidak bekerja & 41 & 45,5 \\
\hline Total & 90 & 100 \\
\hline
\end{tabular}


Pada Tabel 8 didapatkan bahwa kejadian tentamen suicidum di RSJ Prof. H.B. Saanin pada tahun 2013 terbanyak pada orang yang tidak bekerja $(45,6 \%)$

Tabel 9. Data kejadian tentamen suicidum menurut diagnosis psikiatri

\begin{tabular}{llllll}
\hline \multicolumn{2}{c}{ Diagnosis psikiatri } & \multicolumn{1}{c}{$\mathbf{~ k}$} & \multicolumn{1}{c}{$\%$} & \multicolumn{1}{c}{ Fr } & \multicolumn{1}{c}{$\%$} \\
\hline Skizofrenia & paranoid & 31 & 50,0 & 14 & 50,0 \\
& TT & 0 & & 1 & 3,57 \\
& YTT & 2 & 3,23 & 0 & \\
& jumlah & 33 & 53,23 & 15 & 53,57 \\
\hline Skizoafektif & Manik & 3 & 4,84 & 2 & 7,14 \\
& Depresif & 10 & 16,13 & 3 & 10,71 \\
& Campuran & 2 & 3,23 & 0 & \\
& jumlah & 15 & 24,2 & 5 & 17,85 \\
\hline Gangguan & Manik & 4 & 6,45 & 4 & 14,3 \\
Afektif Bipolar & Depresif & 9 & 14,52 & 3 & 10,71 \\
& jumlah & 13 & 20,97 & 7 & 25,01 \\
\hline Gangguan Mental Organik & 1 & 1,6 & 1 & 3,57 \\
\hline Total & & 62 & 100 & 28 & 100
\end{tabular}

Berdasarkan Tabel 9 didapatkan bahwa kejadian tentamen suicidum di RSJ Prof. HB Saanin pada tahun 2013 tertinggi terjadi pada penderita skizofrenia paranoid, baik pada laki-laki $(50 \%)$ maupun pada wanita $(50 \%)$

\section{PEMBAHASAN}

Hasil penelitian yang dilakukan di RSJ H.B. Saanin ini didapatkan bahwa kejadian tentamen suicidum pada pasien rawat inap selama tahun 2013 di RSJ tersebut adalah 4,2\%. Namun hasil ini dianggap belum mencerminkan seluruh kejadian tentamen suicidum yang ada di RSJ tersebut, peneliti menganggap angka kejadian yang sebenarnya kemungkinan besar lebih tinggi dari hasil yang dicantumkan. Hal ini diperkirakan karena tidak lengkapnya data pada status pasien atau karena banyaknya kejadian yang ditutupi oleh keluarga karena merasa malu dan menganggap kalau kejadian tentamen suicidum merupakan aib keluarga.

Hasil penelitian tentang umur didapatkan bahwa kejadian tentamen suicidum tertinggi ditemui pada pasien dewasa yaitu berumur 26-45 tahun baik laki-laki $(53,23 \%)$ maupun wanita $(50 \%)$. Menurut
Kaplan et al sebagian besar bunuh diri sekarang terjadi pada usia 15-44 tahun. ${ }^{11}$ Penelitian ini sesuai dengan studi Wijaya yang mendapatkan bahwa tentament suicidum tinggi pada pasien berumur antara 21-40 tahun sebanyak $38,36 \% .^{10}$ Penelitian ini juga sejalan dengan penelitian Pardede et al yang juga mendapatkan bahwa kejadian bunuh diri lebih sering terjadi pada usia dewasa $(88,5 \%) .{ }^{12} \mathrm{Hal}$ ini mungkin dikarenakan kelompok usia dewasa adalah kelompok usia yang rentan akan depresi terhadap stressor kehidupan seperti masalah ekonomi, pengangguran dan masalah dengan keluarga.

Hasil penelitian menurut jenis kelamin didapatkan bahwa kejadian tentamen suicidum terbanyak dilakukan oleh laki-laki (68,9\%) dibandingkan wanita yang hanya $31,1 \%$. Laki-laki empat kali lebih sering melakukan bunuh diri dibanding wanita. ${ }^{13}$ Penelitian ini juga sejalan dengan penelitian yang dilakukan oleh Hariadi di RSUP Dr. Sardjito Yogyakarta mengemukan bahwa bunuh diri lebih banyak terjadi pada laki-laki dibanding perempuan. $^{14}$

Prevalensi kejadian tentamen suicidum menurut metoda didapatkan bahwa tentamen suicidum pada laki-laki (19,35\%) maupun wanita $(28,57 \%)$ paling banyak menggunakan benda tajam untuk mengakhiri hidupnya. Menurut Kaplan et al sekitar $4 \%$ dari semua pasien psikiatrik pernah memotong dirinya, biasanya menggunakan silet, pisau, pecahan kaca, atau cermin. ${ }^{11}$ Penelitian di atas sama dengan hasil penelitian Wijaya pada tahun 2000 yang mendapatkan bahwa penggunaan benda tajam merupakan kasus terbanyak pada pasien tentamen suicidum baik pada laki-laki $(30,67 \%)$ maupun wanita $(21,15 \%){ }^{10}$ Ini diperkirakan karena benda-benda tajam lebih mudah didapatkan dibandingkan yang lainnya seperti penggunaan zat.

Hasil penelitian kejadian tentamen suicidum berdasarkan agama, maka didapatkan bahwa di RSJ Prof. H.B. Saanin tindakan tentamen suicidum paling banyak dilakukan oleh pasien beragama Islam (93,3\%). Bunuh diri dapat terjadi akibat melonggarnya peraturan, norma-norma dalam masyarakat termasuk agama. Semakin diberi kebebasan terhadap normanorma tersebut, individu semakin mudah melakukan 
tindakan bunuh diri. ${ }^{15}$ Namun hasil yang didapatkan dalam penelitian ini bukan berarti agama Islam dapat dianggap sebagai faktor risiko terjadinya percobaan bunuh diri, karena bisa saja disebabkan karena penderita yang berobat ke RSJ Prof. H.B. Saanin mayoritas beragama Islam. Hasil penelitian Pardede et al pada tahun 2006-2001 di RSUD Dr. Pirngadi, Medan didapati frekuensi tertinggi penderita bunuh diri lebih tinggi pada agama Kristen Protestan (55,8\%) karena mayoritas pasien yang berobat kesana beragama Kristen Protestan. ${ }^{12}$

Hasil penelitian berdasarkan status perkawinan diperoleh bahwa angka kejadian tentamen suicidum tinggi pada pasien yang belum menikah (57,8\%). Penelitian ini sesuai dengan penelitian Pardede et al mendapatkan bahwa bunuh diri lebih tinggi angka kejadiannya pada orang yang belum menikah yaitu sebesar $50,5 \%$. $^{12}$ Wijaya dalam penelitiannya juga menyebutkan bahwa angka kejadian tentament suicidum tinggi pada pasien yang belum menikah $(63,01 \%) .{ }^{10}$ Angka kejadian tentamen suicidum dua kali lebih tinggi pada orang yang belum menikah. ${ }^{11}$ Mungkin status perkawinan dalam penelitian ini dapat menurunkan risiko bunuh diri karena merasa punya tanggung jawab terhadap keluarga terutama pada anak.

Hasil penelitian menurut pendidikan didapatkan angka kejadian tentamen suicidum tertinggi dilakukan oleh pasien dengan tingkat pendidikan SMA-sederajat $(32,2 \%)$, hasil ini tidak jauh berbeda dengan SMPsederajat $(30 \%)$. Penelitian ini sejalan dengan penelitian Wijaya pada tahun 2000 di RSJ Puti Bungsu yang juga mendapatkan bahwa kejadian tentamen suicidum lebih tinggi pada pasien tamat SMA $(47,17 \%) .{ }^{10}$ Perbedaan tingkat pendidikan ini bisa saja karena perbedaan status pasien yang berobat ke RS Jiwa tersebut.

Hasil penelitian tentang pekerjaan didapatkan bahwa orang yang tidak bekerja/pengangguran $(45,6 \%)$ lebih tinggi kecenderungan untuk melakukan tindakan bunuh diri. Hal ini sesuai dengan yang dinyatakan oleh Kaplan et al karena pekerjaaan akan menghalangi bunuh diri, sebab orang yang tidak bekerja akan cenderung mudah depresi dan putus asa
Lemahnya status perekonomian juga menyebabkan kecenderungan untuk bunuh diri. ${ }^{11}$ Penelitian ini sejalan dengan penelitian Wijaya yang mendapatkan bahwa tentament suicidum tinggi pada pengangguran yaitu $31,37 \% .{ }^{10}$ Selain itu mungkin orang yang tidak bekerja merasa hidupnya tidak berguna, depresi dan akhirnya memilih bunuh diri untuk mengakhiri hidupnya karena menganggap hidupnya sia-sia.

Prevalensi tentamen suicidum berdasarkan diagnosis psikiatri didapatkan bahwa angka tertinggi kejadian tentamen suicidum baik pada laki-laki maupun perempuan adalah penderita dengan diagnosa psikiatri Skizofrenia (total 53,23\%), dimana skizofrenia paranoid merupakan jenis kasus terbanyak (50\%). Sebenarnya tidak ada perbedaan khusus antara skizofrenia dengan diagnosis psikiatri lainnya untuk kecenderungan bunuh diri. ${ }^{16}$ Tapi biasanya pada pasien skizofrenia dapat disertai halusinasi berupa suara-suara perintah untuk bunuh diri. ${ }^{1}$ Selain itu bisa saja disebabkan karena diagnosis psikiatri terbanyak pada pasien RS Jiwa H.B. Saanin pada tahun 2013 adalah Skizofrenia Paranoid.

\section{SIMPULAN}

Angka kejadian tentamen suicidum di RSJ H.B. Saanin lebih tinggi pada laki-laki.

Usia dewasa merupakan usia rentan untuk terjadinya tindakan tentamen suicidum.

Kejadian tentamen suicidum di RSJ H.B. Saanin lebih dominan menggunakan benda tajam.

Pengangguran lebih berisiko untuk melakukan tindakan tentamen suicidum.

Tentamen suicidum di RSJ H.B. Saanin angka kejadiannya lebih tinggi pada pemeluk agama Islam dikarenakan mayoritas yang berobat ke RS tersebut adalah beragama Islam.

Angka kejadian tentamen suicidum tinggi pada pasien yang belum menikah baik pada wanita maupun pria.

Orang yang tidak punya pekerjaan cenderung melakukan tindakan tentamen suicidum.

Skizofrenia lebih tinggi melakukan tentamen suicidum dibanding diagnosa psikiatri lainnya. 


\section{DAFTAR PUSTAKA}

1. Hawari D. Psikipatologi bunuh diri. Jakarta: Balai Penerbit FKUI; 2010. hlm.2-13.

2. Maramis WF. Catatan ilmu kesehatan jiwa. Surabaya: Airlangga University Press; 2005.hlm. 63-9.

3. Darmangtyas. Pulung gantung: menyingkap tragedi bunuh diri di Gunung Kidul. 2002.

4. Marliana S. Bunuh diri sebagai pilihan sadar individu-analisa kritis filosofis terhadap konsep bunuh diri Emile Durkheim. Jakarta: Fakultas IImu Budaya Universitas Indonesia; 2012.

5. Bertolote JM, Fleischmann A. A global perspective in the epidemiology of suicide. Suicidology. 2002.

6. Nevid JS, Rathus SA, Green B. Psikologi abnormal. Jakarta: Erlangga. 2005.hlm.263-5.

7. Humsoma R. Bunuh Diri: faktor-faktor penyebab, cara yang ditempuh dan respons komunitas. Jurnal Sosiologi Dilema. 2004;17(1):59-60.

8. Supyanti WE. Pencegahan percobaan bunuh diri pada anak dan remaja dengan gangguan depresi. Denpasar: Fakultas Kedokteran Universitas Udayana; 2010.

9. Rozaki A. Bunuh diri di kalangan remaja Indonesia. Kyoto Review of Southeast Asia. 2012;12.
10. Wijaya RA. Kejadian tentamen suicidum pada penderita gangguan jiwa di RSJ Pusat dan RSJ Puti Bungsu Padang periode 1 Januari 1997-31 Desember 1999. Padang: Universitas Andalas; 2000.

11. Kaplan HI, Sadock BJ, Grebb JA. Sinopsis psikiatri ilmu pengetahuan perilaku psikiatri klinis. Tangerang: Binarupa Aksara Publisher; 2010.

12. Pardede C, Sarumpaet SM, Hisnawati. Karakteristik Penderita Percobaan Bunuh Diri dengan Racun di RS Pirngadi Medan Periode 2006-2011. Medan: Universitas Sumatera Utara; 2012.

13. Kring AM, Johnson SL, Davidson GC, Neale JM. Abnormal psychology. Edisi ke-11. UK: John Wiley\&Sons. 2010. hlm. 246-9.

14. Hariadi B. Karakteristik kasus gantung diri yang diperiksa di instalasi kedokteran forensik RSUP Dr. Sardjito Yogyakarta. Yogyakarta: Universitas Islam Indonesia; 2009.

15. Farzaneh E. Self poisoning suicide attempters among student in Tehran. Iran: Psychiatria Danubia. 2010.

16. Hawton. Schizophrenia and suicide: systemic review of risk factors. The British Journal of Psychiatry. 2005;187:9-20. 